\title{
Analisis Kemandirian dan Kemampuan Keuangan Daerah serta Pengaruhnya Terhadap Pertumbuhan Ekonomi Kabupaten/Kota di Provinsi Sumatera Selatan
}

\author{
Royda1 $^{1}$ dan Dwi Riana ${ }^{2}$ \\ 1-2 Jurusan Manajemen, Universitas Tridinanti Palembang \\ Email: royda@univ-tridinanti.ac.id \\ Email: dwi.riana@sbm-itb.ac.id
}

\begin{abstract}
Fiscal decentralization aims to improve regional finance independency and reduce the fiscal dependency of central goverment. However, in practice, there are still many areas that rely on the assistance central finance for their regional development. The purpose of this study was to determine the level of development of local independence and financial ability as well as effects on economic growth in regency and city in the Sumatera selatan Province year 2008-2018.this research takes place in regency and city in the sumatera selatan province. While the data used in this research is financial data and economic growth 2008-2018 in the sumatera selatan province.

Methods of data analysis in this study there are two kinds, the first is the ratio of local independence and the ratio of local financial ability. Secondly, to investigate the influence of independent variables on the dependent variable used multiple linear regression analysis tool. According to analysis result have been obtained as follows. The ratio of local financial independence of regions indicated by the ratio of the average rate so low, still be between 0\%-25\%. According the ratio of local financial ability of regions averages between 0\%-10\% which is low. Local self-reliance has positive and significant on economic growth. Regional financial capability have positive but not significant effect on economic growth in regency and city in the sumatera selatan province.
\end{abstract}

Key word: local goverment, local finance, local independence

\begin{abstract}
Abstrak
Desentralisasi fiskal bertujuan untuk meningkatkan kemandirian keuangan daerah dan mengurangi ketergantungan fiskal terhadap pemerintah pusat, namun pada pelaksanaannya masih banyak daerah yang bergantung pada bantuan dana pusat untuk pembangunan daerah. Tujuan penelitian ini untuk mengetahui tingkat perkembangan kemandirian dan kemampuan keuangan daerah serta pengaruhnya terhadap pertumbuhan ekonomi di kabupaten/kota provinsi sumatera selatan darti tahun 2008-2018. Penelitian ini dilakukan di 15 kabupaten/kota di provinsi sumatera selatan. Sedangkan data yang digunakan dalam penelitian ini adalah APBD dan laju pertumbuhan ekonomi tahun 2008-2018.

Metode analisis data pada penelitian ini ada dua macam, yang pertama adalah analisis rasio kemandirian dan kemampuan keuangan daerah. Yang kedua, untuk mengetahui pengaruh variabel independen terhadap variabel dependen digunakan alat regresi linier berganda. Berdasarkan hasil analisis yang telah dilakukan diperoleh hasil sebagai berikut: Rasio kemandirian keuangan daerah rata-rata sangat rendah masih disekitar 0\%-25\%, sedangkan untuk rasio kemandirian keuangan daerah juga tergolong masih kurang yaitu rataa-rata berada di antara 0\%-10\%. Kemandirian daerah berpengaruh positif dan signifikan terhadap pertumbuhan ekonomisedangkan kemampuan keuangan daerah berpengaruh positif namun tidak signifikan terhadap pertumbuhan ekonomi kabupaten/kota di provinsi sumater selatan.
\end{abstract}

Kata Kunci: Pemerintah Daerah, Keuangan Daerah, Kemendirian Daerah 


\section{Pendahuluan}

Berkaitan dengan hakikat otonomi daerah, yakni berkenaan dengan pelimpahan wewenang pengambilan keputusan kebijakan, pengelolaan dana publik dan pengaturan kegiatan dalam rangka penyelenggaraan pemerintahan dan pelayanan masyarakat, maka peranan data keuangan daerah sangat dibutuhkan untuk mengidentifikasikan sumber-sumber pembiayaan daerah serta jenis dan besaran belanja yang harus dikeluarkan agar perencanaan keuangan dapat dilaksanakan secara efektif dan efisien. Data keuangan daerah yang memberikan gambaran perkembangan anggaran dan realisasi, baik penerimaan maupun pengeluaran dan analisis terhadapnya merupakan informasi yang penting terutama untuk membuat kebijakan dalam pengelolaan daerah dan melihat kemampuan atau tingkat kemandirian daerah.

Untuk melihat kemampuan dan kemandirian pemerintah daerah dalam menjalankan otonominya, salah satunya bisa diukur melalui kinerja/kemampuan keuangan daerah. Menurut Musgrave \& Musgrave, 1980 (dalam Sumarsono, 2009:14) beberapa variabel yang menunjukkan hal tersebut antara lain : kebutuhan fiskal (fiscal need), kapasitas fiskal (fiscal capacity), upaya fiskal (fiscal effort), derajat desentralisasi fiskal, serta koefisen elastisitas Pendapatan Asli Daerah (PAD) terhadap Product Domestic Regional Bruto (PDRB).

Pengukuran kinerja sangat penting untuk menilai akuntabilitas pemerintah daerah dalam melakukan pengelolaan keuangan daerah. Akuntabilitas bukan sekedar kemampuan menunjukan bagaimana uang publik dibelanjakan, akan tetapi meliputi kemampuan yang menunjukan bahwa uang publik tersebut telah dibelanjakan secara ekonomis, efisien, dan efektif. Sehingga penting bagi pemerintah daerah untuk menaruh perhatian yang lebih besar terhadap kinerja pengelolaan keuangan daerah. Berikut gambaran Pendapatan asli daerah (PAD) kabupaten/kota di Sumatera Selatan.

Tabel 1

Pendapatan Asli Daerah (PAD) Kabupaten/Kota Di Sumatera Selatan

Tahun 2010 - 2017

\begin{tabular}{|c|c|c|c|c|c|c|c|c|}
\hline \multirow{2}{*}{$\begin{array}{l}\text { Kabupaten/ Kota } \\
\text { di Sumsel }\end{array}$} & \multicolumn{8}{|c|}{ PAD Kabupaten/Kota di Sumsel (dalam juta rupiah) } \\
\hline & 2010 & 2011 & 2012 & 2013 & 2014 & 2015 & 2016 & 2017 \\
\hline Kab. Musi Rawas & 20.000 & 30.040 & 35.455 & 53.223 & 60.000 & 72.506 & 76.131 & 90.319 \\
\hline Kota Lubuk Linggau & 12.202 & 15.515 & 22.071 & 25.378 & 28.830 & 30.135 & 35.019 & 37.860 \\
\hline Kab. Musi Banyuasin & 13.285 & 34.574 & 19.512 & 32.570 & 39.773 & 53.749 & 88.207 & 105.766 \\
\hline Kab. Banyuasin & 10.024 & 12.197 & 15.194 & 20.005 & 20.005 & 28.376 & 31.189 & 39.342 \\
\hline Kota Palembang & 103.261 & 113.596 & 155.457 & 196.108 & 224.461 & 263.010 & 458.534 & 509.788 \\
\hline Kab. Ogan Ilir & 10.049 & 12.629 & 16.033 & 15.252 & 25.867 & 16.102 & 30.134 & 63.895 \\
\hline $\begin{array}{l}\text { Kab. Ogan Komering } \\
\text { Ilir (OKI) }\end{array}$ & 13.777 & 11.888 & 25.178 & 30.606 & 30.051 & 37.479 & 41.061 & 54.165 \\
\hline $\begin{array}{l}\text { Kab. Ogan Komering } \\
\text { Ulu (OKU) }\end{array}$ & 12.948 & 21.064 & 28.793 & 37.413 & 38.598 & 39.866 & 42.913 & 42.869 \\
\hline Kab. OKU Timur & 2.681 & 9.555 & 9.587 & 11.087 & 31.717 & 26.487 & 23.041 & 30.864 \\
\hline Kab. OKU Selatan & 1.395 & 2.922 & 5.509 & 4.555 & 6.594 & 13.113 & 13.207 & 13.444 \\
\hline Kota Prabumulih & 9.250 & 12.093 & 15.009 & 16.826 & 21.146 & 24.009 & 26.887 & 33.864 \\
\hline Kab. Muara Enim & 27.044 & 38.020 & 48.255 & 58.121 & 70.908 & 62.161 & 82.716 & 101.100 \\
\hline Kab. Lahat & 18.280 & 20.474 & 26.500 & 40.500 & 35.151 & 51.733 & 76.525 & 62.156 \\
\hline Kab. Empat Lawang & - & - & 7.154 & 6.089 & 10.060 & 10.905 & 14.603 & 16.603 \\
\hline
\end{tabular}




\begin{tabular}{ccccccccc} 
Kota Pagar Alam & 4.182 & 4.683 & 6.277 & 10.000 & 12.502 & 18.957 & 25.966 & 26.170 \\
\hline Total PAD & $\mathbf{2 4 5 . 0 9 3}$ & $\mathbf{3 3 9 . 2 5 0}$ & $\mathbf{4 3 5 . 9 8 4}$ & $\mathbf{5 5 7 . 6 3 3}$ & $\mathbf{1 . 4 9 6 . 6 4 3}$ & $\mathbf{1 . 5 6 3 . 7 0 4}$ & $\mathbf{1 . 8 9 9 . 6 5 0}$ & $\mathbf{2 . 2 8 7 . 0 1 6}$ \\
\hline Sumber : Data diolah & & &
\end{tabular}

Dari Tabel 1.1 di atas, dapat dilihat perkembangan PAD Kabupaten/ Kota di Provinsi Sumatera Selatan periode 2010-2017, dimana selalu terjadi peningkatan PAD setiap tahunnya untuk Provinsi Sumatera Selatan. Akan tetapi cukup fluktuatif untuk Kabupaten Musi Banyu Asin, Banyuasin, Ogan Ilir, Ogan Komering Ilir, OKU Timur, OKU Selatan, Muara Enim, Lahat dan Empat Lawang.

Pembangunan ini memerlukan biaya yang tidak sedikit sehingga peningkatan pembangunan ini akan meningkatkan pengeluaran pemerintah. Untuk dapat memenuhi pengeluaran pemerintah, kabupaten/kota tersebut harus dapat menggali potensi Pendapatan Asli Daerah (PAD) dan tidak bisa hanya dengan mengandalkan dana perimbangan dari pusat. Peningkatan pengeluaran pemerintah akan meningkatkan pertumbuhan ekonomi suatu wilayah.

Pelaksanaan pembangunan menghadapi beberapa kendala, diantaranya perbedaan kualitas sumber daya manusia, keterbatasan sumber daya alam dan sumber dana pembangunan akan memperbesar ketimpangan tingkat kemandirian keuangan daerah antar kabupaten/kota di Sumatera Selatan. Kabupaten/kota yang memiliki sumber dana pembangunan yang tinggi dapat membiayai sebagian besar pengeluaran pemerintah daerahnya, sementara Kabupaten/Kota yang memiliki sumber dana yang rendah memiliki ketergantungan pada dana dari pemerintah pusat.

\section{Perumusan Masalah}

Rumusan masalah penelitian ini adalah sebagai berikut:

a. Bagaimana pengaruh kemandirian keuangan daerah terhadap pertumbuhan ekonomi Kabupaten/ Kota di Sumatera Selatan secara parsial?

b. Bagaimana pengaruh kemampuan keuangan daerah terhadap pertumbuhan ekonomi Kabupaten/Kota di Sumatera Selatan secara parsial?

c. Bagaimana pengaruh kemandirian dan kemampuan keuangan daerah terhadap pertumbuhan ekonomi Kabupaten/Kota di Sumatera Selatan secara simultan?

\section{Landasan Teori}

\section{Otonomi dan Desentralisasi}

Otonomi daerah menurut UU.No. 32 Tahun 2004 adalah hak masyarakat daerah untuk mengatur dan mengelola rumah tangganya sendiri, serta mengembangkan potensi dan sumber daya daerah. Penyelenggaraan otonomi dimaksudkan agar dapat mendorong pemberdayaan masyarakat, menumbuhkan prakarsa dan kreativitas, meningkatkan peran masyarakat serta mengembangkan peran dan fungsi DPRD. Dengan pemberian otonomi kepada daerah, maka sistem yang dianut daerah adalah sistem desentralisasi.

Menurut UU. No. 32 Tahun 2004 desentralisasi adalah penyerahan wewenang pemerintahan oleh pemerintah pusat kepada pemerintah daerah otonom dalam kerangka negara kesatuan Republik Indonesia. Agar daerah otonom tersebut mampu mengatur dan mengurus rumah tangga yang telah diserahkan, maka daerah harus memiliki bermacam-macam kemampuan antara lain keuangan, aparatur, ekonomi dan lain sebagainya. 


\section{Desentralisasi Fiskal}

Desentraliisasi fiskal merupakan pelimpahan wewenang dari pemerintah pusat untuk mengambil keputusan dan pengelolaan fiskal kepada pemerintah daerah. Pelimpahan wewenang tersebut selanjutnya dipertanggungjawabkan secara transparan kepada masyarakat yang bersangkutan (Boex, 2001: 13). Desentralisasi fiskal terdiri dari empat pilar (Boex, 2001: 14), yaitu:

a. Pengeluaran, mengatur mengenai fungsi dan tanggung jawab pengeluaran untuk masing-masing tingkat pemerintahan,

b. Pendapatan, berkenaan dengan sumber-sumber penerimaan objek pajak atau non pajak yang menjadi wewenang pemerintah daerah,

c. Transfer, berkenaan dengan pendapatan yang berasal dari pemerintah pusat, dan

d. Pembiayaan, sebagai penyeimbang antara pendapatan dan pengeluaran daerah.

Desentralisasi Fiskal Daerah menunjukkan seberapa besar ketergantungan pemerintah daerah terhadap pemerintah pusat dalam membiayai pembangunan. Untuk mengetahui seberapa besar tingkat ketergantungan tersebut dilakukan dengan menggunakan ukuran apa yang disebut Derajat Desentralisasi Fiskal dengan berbagai proxy, menurut Abdul Halim, (2007 : 144) sebagai berikut:
a. $\frac{\text { Pendapatan Asli Daerah (PAD) }}{\text { Total Penerimaan Daerah (TPD) }}$
b. $\frac{\text { Bagi Hasil Pajak dan Bukan Pajak untuk Daerah(BHPBP) }}{\text { Total Penerimaan Daerah (TPD) }}$
c. $\frac{\text { Sumbangan Daerah (SB) }}{\text { Total Penerimaan Daerah (TPD) }}$

\section{Kemandirian Keuangan Daerah}

Desentralisasi Fiskal bertujuan untuk memberdayakan dan meningkatkan kemampuan perekonomian daerah, juga untuk menciptakan sistem pembiayaan yang adil, proporsional, rasional, transparan, partisipatif, dan bertanggung jawab, serta untuk mengurangi kesenjangan pembangunan antar daerah (Riyanto dan Siregar, 2005: 15).

Kemandirian keuangan daerah menunjukkan kemampuan pemerintah daerah dalam membiayai sendiri kegiatan pemerintahan, pembangunan, dan pelayanan kepada masyarakat yang telah membayar pajak dan retribusi sebagai sumber pendapatan yang diperlukan daerah (Halim, 2007: 128).

Kemandirian keuangan daerah ini juga menggambarkan tingkat partisipasi masyarakat dalam pembangunan daerah. Semakin tinggi tingkat kemandirian keuangan suatu daerah berarti semakin tinggi partisipasi masyarakat dalam membayar pajak dan retribusi daerah yang merupakan komponen dari PAD.

Tabel 2

Pola Hubungan Tingkat Kemandirian

Dan Kemampuan Keuangan Daerah 


$\begin{array}{ccc}\text { Rendah Sekali } & 0-25 & \text { Instruktif } \\ \text { Rendah } & >25-50 & \text { Konsultatif } \\ \text { Sedang } & >50-75 & \text { Partisipatif } \\ \text { Tinggi } & >75-100 & \text { Delegatif }\end{array}$

Sumber : Dwiranda, $2007: 7$

\section{Kemampuan Keuangan Daerah}

Kriteria penting yang lain untuk mengetahui secara nyata kemampuan daerah dalam mengatur dan mengurus rumah tangganya adalah kemampuan daerah dalam bidang keuangan. Dengan perkataan lain, faktor keuangan merupakan faktor yang penting dalam mengatur tingkat kemampuan daerah dalam melaksanakan otonomi daerah.

Dalam Peraturan Pemerintah No. 105 tahun 2000, menyebutkan bahwa keuangan daerah adalah semua hak dan kewjiban daerah dalam rangka penyelenggaraan pemerintah daerah yang dapat dinilai dengan uang temasuk didalamnya segala bentuk kekayaan lain yang berhubungan dengan hak dan kewajiban daerah tersebut dalam kerangka APBD.

Sebagai pedoman dalam melihat pola hubungan dengan kemampuan daerah (dari sisi keuangan) dapat dikemukakan tabel sebagai berikut :

Tabel 3

Skala Interval Derajat Desentralisasi Fiskal

\begin{tabular}{|c|c|}
\hline$\%$ & Kemampuan Keuangan Daerah \\
\hline $0,00-10,00$ & Sangat Kurang \\
\hline $10,01-20,00$ & Kurang \\
\hline $20,01-30,00$ & Cukup \\
\hline $30,01-40,00$ & Sedang \\
\hline $40,01-50,00$ & Baik \\
\hline$>50,00$ & Sangat baik \\
\hline
\end{tabular}

Sumber : Anita Wulandari (2001: 22)

\section{Pertumbuhan Ekonomi}

Dalam pembangunan ekonomi daerah terdapat suatu proses dimana pemerintah daerah dan masyarakatnya mengelola sumber-sumber daya yang ada dan membentuk suatu pola kemitraan antara pemerintah daerah dengan sektor swasta untuk menciptakan suatu lapangan kerja baru dan merangsang perkembangan kegiatan ekonomi (pertumbuhan ekonomi) dalam wilayah tersebut.

Pertumbuhan ekonomi biasanya diukur dengan pertumbuhan angka-angka pendapatan nasional atau Produk Domestik Bruto. Ukuran ini lebih relevan digunakan karena batas wilayah pengukurannya yang memungkinkan kebijakan pemerintah yang dilakukan untuk meningkatkan laju pertumbuhan tersebut dapat dinilai efektifitasnya. Selanjutnya yang lebih relevan untuk digunakan adalah nilai PDB berdasar harga konstan daripada PDB atas dasar harga berlaku.

Untuk membangun suatu pengukuran perubahan kuantitas output (dan bukan perubahan harga output), yang disebut GDP riil. Pengukuran output ini dalam harga konstan atau nilai mata uang yang konstan dari tahun dasar (Froyen, 2009: 33).

\section{Kerangka Penelitian}

Kerangka pikir penelitian ini dapat digambarkan melalui diagram berikut ini : 


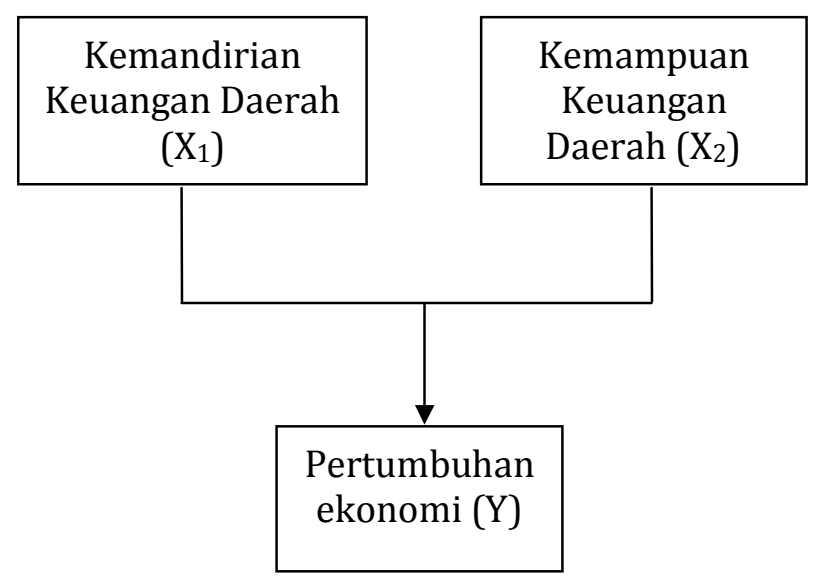

Gambar 1. Kerangka Pemikiran

\section{Hipotesis}

a. Variabel Kemandirian Keuangan Daerah berpengaruh terhadap Pertumbuhan Ekonomi Kab/Kota Provinsi Sumatera Selatan

b. Variabel Kemampuan keuangan Daerah berpengaruh terhadap Pertumbuhan Ekonomi Kab/Kota Provinsi Sumatera Selatan

c. Kemampuan dan kemandirian keuangan daerah diduga berpengaruh terhadap pertumbuhan ekonomi Kabupaten/ Kota di Sumatera.

\section{Metode Penelitian}

Lokasi Penelitian

Adapun lokasi Penelitian ini dilakukan di 15 Kabupaten/ Kota di Provinsi Sumatera Selatan

\section{Jenis Penelitian}

Jenis penelitian ini adalah penelitian inferensial melakukan analisis hubungan antar variabel dengan pengujian hipotesis. Dengan demikian, kesimpulan penelitian jauh melebihi sajian data kuantitatif saja, dan kesimpulannya adakalanya bersifat umum.

\section{Jenis Data}

Data yang digunakan adalah data panel, yaitu gabungan dari time series dan cross section selama 11 tahun yaitu dari tahun 2008 sampai dengan 2018 meliputi Pendapatan Asli Daerah (PAD), Dana alokasi Umum, Belanja Daerah, Pendapatan Daerah, Dana Perimbangan dan PDRB Kabupaten/ Kota di Sumatera Selatan. Selain itu digunakan data sekunder lainnya seperti pustaka yang berhubungan dengan penelitian ini.

\section{Teknik Analisis Data}

\section{Analisis Kualitatif}

Analisis kualitatif adalah analisa yang berdasarkan data dan dinyatakan dalam bentuk uraian. Data ini merupakan data yang berupa informasi uraian dalam bentuk bahasa prosa kemudian dikaitkan dengan data lainnya untuk mendapatkan kejelasan atau menguatkan suatu gambaran yang telah ada. 


\section{Analisis Kuantitatif}

Analisis kuantitatif digunakan untuk memecahkan masalah-masalah yang bersifat pengukuran kuantitas (jumlah dan angka). Pendekatan ini berawal dari data yang diproses menjadi informasi yang berharga bagi pengambilan keputusan. berikut:

Analisis data yang digunakan dalam penelitian ini melalui tahap-tahap sebagai

- Untuk mengukur Kemampuan keuangan daerah digunakan Derajat Otonomi Fiskal (DOF)

$$
\begin{aligned}
& D O F i=\frac{P A D i}{T P D i} x 100 \% \quad \ldots \ldots \ldots \ldots \ldots \ldots \ldots \ldots \ldots \text { (6.1) } \\
& \text { Dimana : DOF : Derajat Otonomi Fiskal } \\
& \text { PAD : Pendapatan Asli Daerah } \\
& \text { TPD : Total Penerimaan Daerah } \\
& \text { i : Kabupaten/ Kota di Provinsi Sumatera Selatan }
\end{aligned}
$$

- Untuk mengukur tingkat kemandirian keuangan daerah digunakan Rasio Kemandirian Keuangan Daerah (RKKD)

$$
\begin{aligned}
& \text { RKKD }= \frac{P A D}{\text { Dana Perimbangan }} \times 100 \% \quad \ldots \ldots \ldots \ldots \ldots \ldots \ldots \ldots \\
& \text { Dimana }: \text { RKKD }: \text { Rasio Kemandirian Keuangan Daerah } \\
& \text { PAD } \quad: \text { Pendapatan Asli Daerah } \\
& \mathrm{i} \quad: \text { Kabupaten/ Kota di Provinsi Sumatera Selatan }
\end{aligned}
$$

- Untuk mengukur tingkat pertumbuhanekonomi $\left(\mathrm{r}_{\mathrm{t}}\right)$ digunakan rumus berikut :

$$
\begin{aligned}
& \text { rit }=\frac{\text { PDRBit }- \text { PDRBit }-1}{\text { PDRBit }-1} \times 100 \% \\
& \text { Dimana : } r \text { : Pertumbuhan ekonomi } \\
& \text { PDRB : Produk Domestik Regional Bruto } \\
& \text { i : Kabupaten/ Kota di Provinsi Sumatera Selatan } \\
& \mathrm{t} \quad \text { : Tahun } \mathrm{t} \\
& \text { t-1 : Tahun } \mathrm{t}-1
\end{aligned}
$$

- Untuk mengukur tingkat kemandirian keuangan daerah terhadap pertumbuhan ekonomi di gunakan rumus di bawah ini :

$$
\begin{array}{cl}
E i=\frac{\Delta R K K D i}{\Delta r i t} \times \frac{r i t}{R K K D i} & \ldots \ldots \ldots \ldots \ldots \ldots \ldots \ldots \\
\text { Dimana: } & \\
\text { RKKD } & : \text { Rasio Kemandirian Keuangan Daerah } \\
\mathrm{r} & : \text { Pertumbuhan Ekonomi } \\
\Delta & : \text { Perubahan } \\
\mathrm{i} & : \text { Kabupaten/ Kota di Provinsi Sumatera Selatan } \\
\mathrm{t} & : \text { Tahun } \mathrm{t}
\end{array}
$$

- Untuk mengetahui besarnya pengaruh kemandirian dan kemampuan keuangan daerah terhadap pertumbuhan ekonomi Kabupaten/ Kota di Provinsi Sumatera Selatan, digunakan model regresi berganda.

$$
\begin{array}{lll}
\text { Dimana: } & \mathrm{Y}_{1 \mathrm{t}} & \text { : Pertumbuhan Ekonomi } \\
\mathrm{X}_{1} & \text { : Rasio kemandirian keuangan daerah (RKKD) } \\
\mathrm{X}_{2} & \text { : Derajat otonomi fiskal (DOF) } \\
\mathrm{e}_{1 \mathrm{t}} & : \text { Variabel pengganggu yang tidak diamsukkan dalam model }
\end{array}
$$




\author{
$\mathrm{t} \quad$ : Tahun $\mathrm{t}$ \\ $a, b_{1}, b_{2}, b_{3}$ : Konstanta
}

\title{
Hasil Analisis dan Pembahasan Analisis Rasio Kemandirian Keuangan Daerah
}

Untuk mengukur kemampuan keuangan daerah pada kabupaten dan kota provinsi sumatera selatan dilakukan dengan melihat rasio kemandirian keuangan daerah.

Tabel 4

Rasio Kemandirian Keuangan Daerah Kabupaten/Kota Pro. Sumatera Selatan

\begin{tabular}{|c|c|c|c|c|c|c|c|c|c|c|c|}
\hline Nama Daerah & 2008 & 2009 & 2010 & 2011 & 2012 & 2013 & 2014 & 2015 & 2016 & 2017 & 2018 \\
\hline Prov. Sumatera Selatan & 64,32 & 78,08 & 94,99 & 84,07 & 86,15 & 86,47 & 64,62 & 85,36 & 100,74 & 58,28 & 113,83 \\
\hline Kab. Lahat & 4,71 & 5,92 & 5,35 & 7,12 & 8,98 & 6,20 & 7,40 & 8,43 & 7,54 & 10,27 & 9,39 \\
\hline Kab. Musi Banyuasin & 1,50 & 2,95 & 3,15 & 3,12 & 4,50 & 4,31 & 3,93 & 10,01 & 8,83 & 8,91 & 9,89 \\
\hline Kab. Musi Rawas & 4,46 & 6,44 & 6,11 & 7,14 & 7,23 & 6,90 & 9,27 & 9,20 & 7,36 & 9,83 & 9,49 \\
\hline Kab. Muara Enim & 6,92 & 6,75 & 8,74 & 6,45 & 7,37 & 7,74 & 9,50 & 10,11 & 9,11 & 8,77 & 11,29 \\
\hline Kab. Ogan Komering Ilir & 3,60 & 3,90 & 4,09 & 4,17 & 4,04 & 4,52 & 4,99 & 10,68 & 20,51 & 20,01 & 22,52 \\
\hline Kab. Ogan Komering Ulu & 5,27 & 7,19 & 7,91 & 6,78 & 6,08 & 5,27 & 8,00 & 12,25 & 11,00 & 8,57 & 17,52 \\
\hline Kota Palembang & 16,87 & 20,69 & 23,51 & 24,39 & 39,12 & 34,58 & 43,46 & 51,57 & 48,41 & 45,96 & 52,89 \\
\hline Kota Prabumulih & 4,29 & 4,50 & 5,44 & 5,45 & 5,56 & 6,02 & 8,09 & 10,96 & 10,86 & 14,31 & 16,21 \\
\hline Kota Pagar Alam & 1,82 & 2,98 & 3,61 & 4,55 & 5,96 & 5,22 & 5,84 & 6,13 & 7,07 & 8,12 & 8,73 \\
\hline Kota Lubuk Linggau & 6,80 & 7,55 & 8,67 & 6,76 & 7,29 & 7,08 & 7,44 & 9,21 & 11,48 & 12,05 & 15,82 \\
\hline Kab. Banyuasin & 2,34 & 2,76 & 2,78 & 3,43 & 3,20 & 3,24 & 4,98 & 7,39 & 6,70 & 7,57 & 7,77 \\
\hline Kab. Ogan Ilir & 2,77 & 2,40 & 4,20 & 2,52 & 4,19 & 7,79 & 9,14 & 5,29 & 19,21 & 26,53 & 19,60 \\
\hline Kab. OKU Timur & 1,68 & 1,81 & 5,22 & 3,99 & 3,15 & 3,49 & 3,84 & 5,62 & 4,36 & 5,59 & 6,10 \\
\hline Kab. OKU Selatan & 1,42 & 1,16 & 1,62 & 2,62 & 2,37 & 2,04 & 2,80 & 5,05 & 4,69 & 5,03 & 4,71 \\
\hline Kab. Empat lawang & 5,36 & 1,80 & 2,68 & 2,26 & 3,17 & 2,94 & 3,07 & 3,35 & 4,37 & 5,10 & 5,74 \\
\hline
\end{tabular}

Sumber: data diolah

Berdasarkan tabel rasio diatas dapat disimpulkan bahwa rasio kemandirian keuangan daerah selama 11 tahun pada kabupaten/kota di provinsi sumatera selatan rata-rata masih dalam kategori rendah sekali (RS) dengan pola hubungan instruktif. Akan tetapi untuk provinsi sumatera seatan secara keseluruhan masuk pada kategori Tinggi dengan pola hubungan Delegatif. Untuk kabupaten/kotanya sendiri masih sangat rendah kecuali satu kota yang masuk kategori rendah dan sedang yaitu kota palembang. Hampr keseluruhan Kabupaten dan kota yang masuk kategori rendah sekali dengan pola hubungan instruktif artinya kemandirian keuangan daerah di masing-masing kabupaten dan kota sumatera selatan masih sangat tergantung dengan pemerintah pusat.

Menurut uraian dan perhitungan diatas dapat disimpulkan bahwa rasio kemandirian keuangan daerah untuk kabupaten dan kota di provinsi sumatera selatan selama 11 tahun terakhir masih sangat kurang , karena masih dalam skala interval 0\% $25 \%$ dan ini berarti dapat disebabkan pada sumber penerimaan daerah dan dasar pengenaan biaya. Pendapatan asli daerah masih belum dapat diandalkan karena daerah 
masih belum mengoptimalkan sumber-sumber pendapat daerahnya, juga karena masih rendahnyabasis pjak/retribusi pada masing-daerah daerah.

\section{Analisis Rasio Kemampuan Keuangan Daerah}

Untuk mengukur tinggi rendahnya kemampuan keuangan daerah dapat dilihat pada derajat desentralisasi fiskal masing-masing daerah. Nilai rasio-rasionya ditunjukkan pada tabel dibawah ini.

Tabel 5

Rasio Keuangan Daerah Kab/Kota Prov. Sumatera Selatan

\begin{tabular}{|c|c|c|c|c|c|c|c|c|c|c|c|}
\hline Nama daerah & 2008 & 2009 & 2010 & 2011 & 2012 & 2013 & 2014 & 2015 & 2016 & 2017 & 2018 \\
\hline Prov. Sumatera Selatan & 39,01 & 43,69 & 47,79 & 45,52 & 38,46 & 39,65 & 34,78 & 38,71 & 38,84 & 36,80 & 52,55 \\
\hline Kab. Lahat & 4,35 & 5,11 & 4,49 & 6,00 & 7,39 & 5,17 & 5,86 & 6,50 & 5,36 & 7,72 & 7,00 \\
\hline Kab. Musi Banyuasin & 1,42 & 2,72 & 2,91 & 2,91 & 4,16 & 3,96 & 3,66 & 8,38 & 7,67 & 7,46 & 7,87 \\
\hline Kab. Musi Rawas & 4,08 & 5,42 & 5,60 & 6,11 & 6,30 & 6,00 & 7,55 & 7,40 & 6,21 & 7,92 & 7,18 \\
\hline Kab. Muara Enim & 6,29 & 5,78 & 7,60 & 5,40 & 6,26 & 6,52 & 7,72 & 8,18 & 7,11 & 7,23 & 8,31 \\
\hline Kab. Ogan Komering Ilir & 3,32 & 3,53 & 3,67 & 3,54 & 3,40 & 3,72 & 4,17 & 8,66 & 14,66 & 14,37 & 15,97 \\
\hline Kab. Ogan Komering Ulu & 4,82 & 6,39 & 6,57 & 5,70 & 5,30 & 4,30 & 6,47 & 9,31 & 8,16 & 7,04 & 12,17 \\
\hline Kota Palembang & 13,03 & 15,23 & 16,98 & 15,52 & 22,98 & 20,13 & 23,24 & 25,65 & 26,05 & 28,35 & 28,97 \\
\hline Kota Prabumulih & 3,82 & 4,07 & 4,85 & 4,64 & 4,87 & 5,26 & 6,64 & 8,83 & 9,21 & 11,62 & 13,04 \\
\hline Kota Pagar Alam & 1,74 & 2,79 & 3,26 & 4,06 & 5,12 & 4,52 & 5,07 & 5,15 & 5,72 & 7,07 & 7,60 \\
\hline Kota Lubuk Linggau & 6,11 & 6,46 & 6,83 & 5,29 & 6,38 & 5,85 & 5,49 & 6,78 & 8,21 & 10,23 & 12,06 \\
\hline Kab. Banyuasin & 2,08 & 2,38 & 2,43 & 2,74 & 2,66 & 2,62 & 3,96 & 5,86 & 4,94 & 5,83 & 5,68 \\
\hline Kab. Ogan Ilir & 2,51 & 2,26 & 3,75 & 2,15 & 3,67 & 6,27 & 7,47 & 4,24 & 12,66 & 17,80 & 13,14 \\
\hline Kab. OKU Timur & 1,52 & 1,55 & 4,46 & 3,29 & 2,78 & 3,00 & 3,15 & 4,30 & 3,43 & 4,12 & 4,43 \\
\hline Kab. OKU Selatan & 1,31 & 1,03 & 1,41 & 2,19 & 2,20 & 1,82 & 2,49 & 4,21 & 3,42 & 3,82 & 3,42 \\
\hline Kab. Empat lawang & 4,60 & 1,70 & 2,49 & 2,04 & 2,82 & 2,60 & 2,72 & 2,90 & 3,65 & 4,11 & 4,42 \\
\hline
\end{tabular}

Sumber: data diolah

Berdasarkan tabel rasio kemampuan keuangan daerah diatas dapat dilihat bahwa rata-rata rasio masing-masing daerah meningkat tiap tahunnya walaupun masih dalam skala interval sangat kurang. Namun apabila dilihat hanya Provinsi Sumatera Selatan saja maka rata-rata intervalnya masuk ke skala baik. Ada beberapa Kabupaten dan Kota yang peningkatannya cukup baik untuk 3 tahun terakhir yaitu kota palembang yang sudah masuk skala interval cukup baik, sedangkan daerah-daerah lainnya diantaranya Kabupaten OKI, Kota Lubuk Linggau, Kabupaten Ogan Ilir dan Kota Prabumulih.

Melihat dari rasio yang ditampilkan diatas, dapat disimpulkan bahwa rata-rata Kabupaten dan Kota di Provinsi Sumatera Selatan masih pada skala interval sangat kurang. Ini berarti bahwa pendapatan asli daerah mempunyai kemampuan yang masih sangat rendah dalam membiayai pembangunan daerah.hal ini terjadi karena PAD Kabupaten dan Kota di Provinsi Sumatera Selatan masih relatif sangat kecil dibandingkan dengan total pendapatan daerahnya. Sehingga dalam membiayai pelaksanaan pemerintah dan pembangunannya masih sangat tergantung pada sumber keuangan yang berasal dari pemerintah pusat.

Berdasarkan uraian di atas, bahwa untuk mengatasi masalah tersebut pemerintah daerah harus mampu mengoptimalkan sumber-sumber pendapatan daerahnya. Pemerintah harus mencari alternatif yang memungkinkan untuk dapat mengatasi 
kekurangan pembiayaan untuk melaksanakan pemerintah dan program pembangunan yang berkelanjutan.

\section{Deskripsi Statistik Kuantitatif Uji Asumsi Klasik Uji Normalitas}

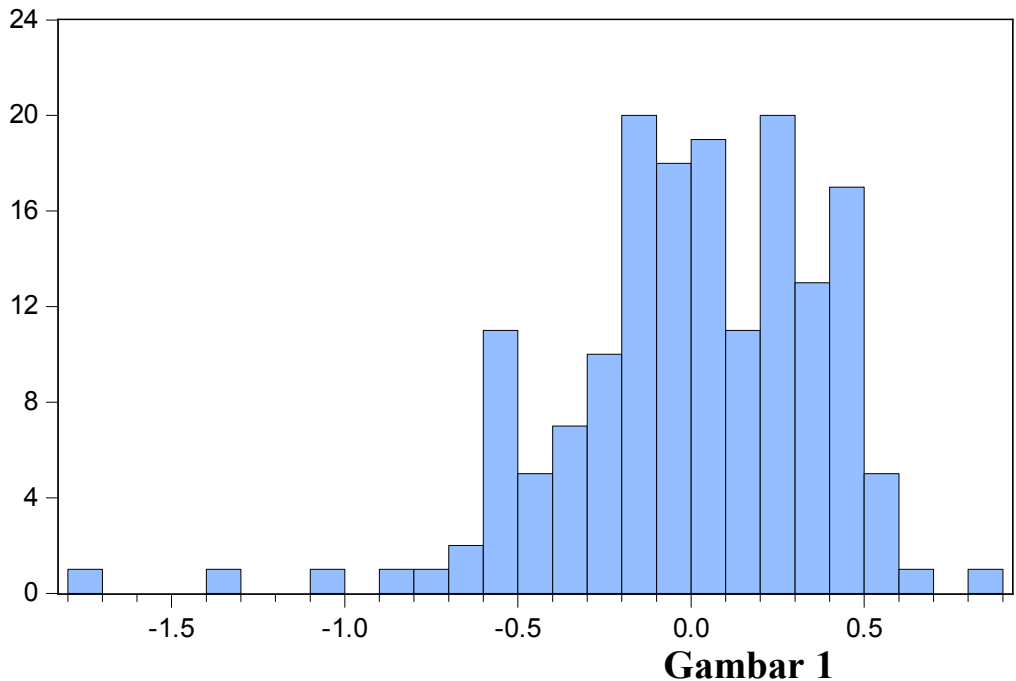

\begin{tabular}{lc|}
\hline Series: Standardized Residuals \\
Sample 2008 2018 \\
Observations & 165 \\
& \\
Mean & $-1.43 e-17$ \\
Median & 0.021280 \\
Maximum & 0.839434 \\
Minimum & -1.731309 \\
Std. Dev. & 0.379139 \\
Skewness & -1.026564 \\
Kurtosis & 5.493516 \\
& \\
Jarque-Bera & 71.72656 \\
Probability & 0.000000
\end{tabular}

Salah satu asumsi dalam model regresi liniear adalah distribusi probabilitas gangguan $\mu$ i memiliki rata-rata yang diharapkan sama dengan nol, tidak berkolerasi dan mempunyai varian konstan. Uji normalitas bertujuan untuk melihat bahwa suatu data berdistribusi normal atau tidak. Untuk menguji apakah data berdistribusi normal atau tidak, dilakukan uji jarque-bera.

Dari histogram, dapat dilihat bahwa nilai JB sebesar 71,72656 sedangkan nilai chi square yang dilihat dari jumlah variable independent $\mathrm{k}=2$, maka $\mathrm{df}=165-2=163$ dengan alpha 5\% yakni sebesar193,791. Nilai JB < Chi square menyimpulkan bahwa data dalam penelitian ini terdistribusi normal.

\section{Uji Multikolinearitas}

Tabel 6

Uji Multikolinearitas

\begin{tabular}{|c|c|c|c|}
\hline & $\mathbf{Y}$ & $\mathbf{X}_{\mathbf{1}}$ & $\mathbf{X}_{\mathbf{2}}$ \\
\hline $\mathbf{Y}$ & 1.000000 & 0.737760 & 0.465756 \\
\hline $\mathbf{X}_{\mathbf{1}}$ & 0.737760 & 1.000000 & 0.553605 \\
\hline $\mathbf{X}_{\mathbf{2}}$ & 0.465756 & 0.553605 & 1.000000 \\
\hline
\end{tabular}

Model yang baik adalah nilai $\mathrm{R}^{2}$ tingginya tidak lebih tinggi dari 0,80. Dari tabel dapat disimpulkan bahwa tidak terjadi q korelasi antar variable independent. 


\section{Uji Heterokedastisitas}

Tabel 7

Uji Heterokedastisitas

\begin{tabular}{lcccc}
\hline \hline \multicolumn{1}{c}{ Variable } & Coefficient & Std. Error & t-Statistic & Prob. \\
\hline \hline \multicolumn{1}{c}{$\mathrm{X}_{1}$} & 0.395132 & 0.050573 & 7.813045 & 0.0000 \\
$\mathrm{X}_{2}$ & 0.092774 & 0.096068 & 0.965716 & 0.3358 \\
$\mathrm{C}$ & 8.276687 & 1.035897 & 7.989871 & 0.0000 \\
\hline \hline & Effects Specification & \\
\hline \hline Cross-section fixed (dummy variables) & & 13.86061 \\
\hline \hline R-squared & & & 0.642945 \\
Adjusted R-squared & 0.652264 & Mean dependent var & 1.098154 \\
S.E. of regression & 0.614671 & S.D. dependent var & 1.418160 \\
Sum squared resid & 0.399107 & Akaike info criterion & 1.228056 \\
Log likelihood & 23.57440 & Schwarz criterion & 1.614810 \\
F-statistic & -73.59769 & Hannan-Quinn criter. & \\
Prob(F-statistic) & 17.35063 & Durbin-Watson stat & \\
\hline \hline
\end{tabular}

Berdasarkan tabel diatas, dapat terlihat nilai $\mathrm{R}^{2}$ sebesar 0,652264 . Nilai chi square hitung diperoleh dari nilai $\mathrm{R}^{2}$ dikali dengan nilai observasi yakni sebesar $0,652264 \times 165=107,6236$. Sedangkan nilai chi square table adalah 193,791. Dikarenakan nilai chi square hitung lebih kecil daripada chi square tabel, maka disimpulkan bahwa tidak terdapat permasalahan heteroskedastisitas pada penelitian ini.

\section{Uji Autokorelasi}

Uji yang dikenal untuk mendeteksi autokolerasi adalah uji Durbin Watson (DW), Gujarati (2007:121). Adapun untuk melihat ada tidaknya autokolerasi dalam hasil regresi dapat dilihat dari nilai Durbin-Watson statistiknya.

Dari table regresi pada metode fixed effect, nilai DW sebesar 1.614810. Jika nilainya mendekati angka 2, maka tidak terjadi autokorelasi. Sebaliknya, jika mendekati angka 0 atau 4, maka akan terjadi masalah autokorelasi (+/-).

\section{Hasil Estimasi Regresi Data Panel Uji Simultan (Uji F)}

Hasil regresi dari pengarus kemandirian dan kemampuan keuangan daerah terhadap pertumbuhan ekonomi di kabupaten dan kota provinsi sumatera selatan tahun 2008-2018 dengan menggunakan taraf keyakinan 95\% ( $\alpha=5 \%)$, dengan $\mathrm{df}=165$, dapat dilihat berdasarkan uji F, nilai $\mathrm{F}$ statisti sebesar 17,3506 lebih besar dari nilai $\mathrm{F}$ kritis (F tabel) pada $\alpha=5 \%$, $\mathrm{df}=165$ yaitu sebesar 3,05. Artinya seleruh variabel bebas yaitu kemandirian dan kemampuan keuangan daerah dalam model memiliki pengaruh yang nyata terhadap variabel terikat yaitu pertumbuhan ekonomi pada tingkat keyakinan 95\% atau bahkan 99\%. Signifikasi kedua variabel bebas ditunjukkan juga oleh nilai $\mathrm{F}=$ 
$0,0000<0,05$ (yakni nilai $\alpha=5 \%$ ) atau bahkan probabilitas $\mathrm{F}=0,0000<0,01$ (yakni nilai $\alpha=1 \%$ ).

Berdasarkan uji simultan tersebut dapat dijelaskan bahwa kedua variabel bebas yaitu kemandirian dan kemampuan keuangan daerah memiliki pengaruh yang kuat terhadap laju pertumbuhan ekonomi.

\section{Uji Signifikansi Parsial (Uji T)}

Berdasarkan output estimasi regresi data panel dengan metode FEM di atas, maka hasil estimasi tersebut dapat diringkas sebagaimana tabel dibawah ini.

Tabel 8

Nilai t-Statistik

Dependent Variable: $Y$

Method: Panel Least Squares

Date: 08/19/19 Time: 01:54

Sample: 20082018

Periods included: 11

Cross-sections included: 15

Total panel (balanced) observations: 165

\begin{tabular}{lrlrl}
\hline \hline Variable & Coefficient & Std. Error & t-Statistic & Prob. \\
\hline \hline $\mathrm{X}_{1}$ & 0.395132 & 0.050573 & 7.813045 & 0.0000 \\
$\mathrm{X}_{2}$ & 0.092774 & 0.096068 & 0.965716 & 0.3358 \\
$\mathrm{C}$ & 8.276687 & 1.035897 & 7.989871 & 0.0000 \\
\hline \hline & & & \\
\hline \hline Cross-section fixed (dummy variables) & & \\
\hline \hline R-squared & & & \\
Adjusted R-squared & 0.652264 & Mean dependent var & 13.86061 \\
S.E. of regression & 0.614671 & S.D. dependent var & 0.642945 \\
Sum squared resid & 0.399107 & Akaike info criterion & 1.098154 \\
Log likelihood & 23.57440 & Schwarz criterion & 1.418160 \\
F-statistic & -73.59769 & Hannan-Quinn criter. & 1.228056 \\
Prob(F-statistic) & 17.35063 & Durbin-Watson stat & 1.614810 \\
& 0.000000 & & \\
\hline
\end{tabular}

Dari tabel diatas maka persamaan regresi yang tercipta adalah:

$$
Y_{1 t}=8.2766+0.3951 X_{1}+0.0927 X_{2}
$$

Nilai $\mathrm{t}=\alpha$ semua variabel, ternyata lebih kecil dari t-hitung pada $\alpha=5 \%$ yaitu 1,6543, maka Ho ditolak yang artinya semua variabel bebas pada penelitian ini berpengaruh terhadap variabel terikat.

\section{Uji koefisien Determinan (Adjusted R ${ }^{2}$ )}

Hasil koefisien determinan pada intinya mengukur seberapa jauh kemampuan model dalam menerangkan variasi variabel dependen secara statistik dengan nilai 
koefisien determinasi $\left(\mathrm{R}^{2}\right)=0,6522$, hal ini berarti bahwa 65 persen pertumbuhan ekonomi di 15 kabupaten/kota di provinsi Sumatera Selatan dapat dijelaskan oleh variabel kemandirian dan kemampuan keuangan daerah. Sedangkan 35 persen dijelaskan oleh variabel lain diluar model atau faktor-faktor lain diluar penelitian ini.

\section{Pengaruh Kemandirian Keuangan Daerah Terhadap Pertumbuhan Ekonomi Kabupaten/Kota Di Provinsi Sumatera Selatan}

Pada regresi data panel menunjukkan bahwa variabel kemandirian keuangan daerah dalam jangka pendek signifikan $(0,0000)$. Hal tersebut sesuai dengan hipotesis yang digunakan dalam penelitian, dimana kemandirian keuangan daerah berpengaruh terhadap pertumbuhan ekonomi di Kabupaten/kota Provinsi sumatera Selatan. Halim (2008) mengemukakan bahwa Kemandirian keuangan daerah ditunjukan oleh besar kecilnya pendapatan asli daerah dibandingkan dengan pendapatan daerah yang berasal dari sumber lain, misalnya bantuan pemerintah pusat ataupun dari pinjaman.

Indikator kemandirian keuangan daerah ini diukur dengan menggunakan rasio pendapatan asli daerah dibagi dengan total pendapatan daerah. Mengetahui kemandirian keuangan daerah ini dapat menunjukkan seberapa besar local taxing power suatu daerah, serta seberapa besar kemampuan PAD dalam mendanai belanja daerah yang dianggarkan untuk memberikan pelayanan publik kepada masyarakat. Rasio kemandirain keuangan daerah ini apabila hasil semakin tinggi maka akan semakin kecil angka ketergantungan daerah terhadap pihak lain (pemerintah pusat khususnya) dan berlaku sebaliknya. Dengan melihat hubungan antara rasio kemandirian keuangan daerah terhadap pertumbuhan ekonomi yang dianalisis dengan regresi berganda dengan menggunakan alat analisis eviews maka dapat terlihat bahwa rasio salah satu pertumbuhan ekonomi suatu daerah dapat pula dipengaruhi oleh rasio kemandirian daerah, apabila daerah tersebut tingkat kemandiriannya tinggi maka akan berpengaruh signifikan terhadap pertumbuhan ekonominya.

\section{Pengaruh Kemampuan Keuangan Daerah Terhadap Pertumbuhan Ekonomi Kabupaten/Kota Di Provinsi Sumatera Selatan}

Pada regresi data panel menunjukkan bahwa variabel kemandirian keuangan daerah dalam jangka pendek signifikan (0,3358). Hal tersebut tidak sesuai dengan hipotesis yang digunakan dalam penelitian, dimana kemampuan keuangan daerah berpengaruh terhadap pertumbuhan ekonomi di Kabupaten/kota Provinsi sumatera Selatan.

Keuangan daerah sebagai salah satu indikator untuk mengetahui kemampuan daerah dalam mengatur dan mengurus rumah tangganya sendiri. Dengan dikeluarkannya undang-undang tentang Otonomi Daerah, membawa konsekuensi bagi daerah yang akan menimbulkan perbedaan antar daerah yang satu dengan yang lainnya, terutama dalam hal kemampuan keuangan daerah. Hasil analisi regresi yang menunjukkan bahwa tidak signifikannya pengaruh kemampuan keuangan daerah terhadap pertumbuhaan ekonomi ini mungkin disebabkan sedikit atau bahkan tidak terlalu terlihat hubungan antara tingkat kemampuan daerah terhadap pertumbuhan ekonomi. Perubahan yang terjadi pada pertumbuhan ekonomi baik naik atau turunnya tidak terlalu dipengaruhi oleh tingkat rasio kemampuan keuangan daerah, mungkin ada faktor-faktor lain yang lebih mempengaruhi pertumbuhan ekonomi suatu daerah diantaranya seperti rasio kemandirian daerah. 


\section{Kesimpulan}

Berikut ini beberapa kesimpulan dari hasil penelitian :

a. Berdasarkan analisis rasio kemandirian dan kemampuan keuangan daerah dapat disimpulkan bahwa bahwa rasio kemandirian keuangan daerah untuk kabupaten dan kota di provinsi sumatera selatan selama 11 tahun terakhir masih sangat kurang, karena masih dalam skala interval 0\% - 25\% dan untuk rasio kemampuan keuangan daerah juga masih di angka 0\% 10\%. Ini berarti dapat disebabkan pada sumber penerimaan daerah dan dasar pengenaan biaya. Pendapatan asli daerah masih belum dapat diandalkan karena daerah masih belum mengoptimalkan sumber-sumber pendapat daerahnya, juga karena masih rendahnyabasis pjak/retribusi pada masing-daerah daerah.

b. Kemandirian keuangan daerah $\left(\mathrm{X}_{1}\right)$ berpengaruh signifikan terhadap Pertumbuhan ekonomi (Y) Kabupaten/Kota di Provinsi Sumatera Selatan, dimana nilai signifikansi Kemandirian keuangan daerah terhadap Pertumbuhan ekonomi sebesar $0,00>0,05$.

c. Kemampuan keuangan daerah $\left(\mathrm{X}_{2}\right)$ tidak berpengaruh signifikan terhadap Pertumbuhan ekonomi (Y) di kabupaten/Kota di Provinsi Sumatera Selatan dimana nilai signifikansi upah terhadap inflasi sebesar 0,335 >0,05.

\section{Saran}

Berikut ini adalah beberapa saran yang didapat dari hasil kesimpulan penelitian diantaranya :

1. Diharapkan kepada pemerintah agar pada pelaksanaan otonoi daerah, kontribusi kemandirian dan kemamuan keuangan daerah perlu diperhatikan daan ditingkatkan agar daerah dapat mengurangi ketergantungannya terhadap pemerintah pusat.

2. Diharapkan kepada pemerintah untuk lebih menggali potensi-potensi daerah yang akan menjadi sumber pendapatan asli daerah guna membantu pertumbuhan ekonomi daerah tersebut.

\section{Ucapan Terima Kasih}

Terima Kasih tim peneliti ucapkan kepada Kementrian Ristekdikti yang telah memberikan dukungan moril dan bantuan Dana Penelitian untuk Penelitian Dosen Pemula (PDP) No. 108/SP2H/LT/DRPM/2019 Tanggal 11 Maret 2019 kepada tim peneliti.

\section{Referensi}

Boex, J., R. Kampanje, and R. Mwadiwa. 2001. Malawi Intergovernmental Fiscal Transfers Study. Government of Malawi / UNCDF.

Dwiranda, et.al, 2007. Pengaruh Pendapatan Asli Daerah (PAD) pada Belanja Modal dengan Pertumbuhan Ekonomi sebagai Variabel Moderating di Kabupaten/Kota di Provinsi Bali. Bali

FROYEN, R.T., 2009. Macroeconomics: Theories and Policies. (9e). Upper Saddle River, New Jersey: Prentice Hall. 
Halim, \& Theresia. (2007). Seri Bunga Rampai Manajemen Keuangan Daerah Pengelolaan Keuangan Daerah (Ed. 2). Yogyakarta: UPP STIM YKPN.

Siregar, Riyanto. (2005). Analisis Pengaruh Kinerja Keuangan Daerah terhadap Pertumbuhan Ekonomi Provinsi Riau dengan Belanja Modal sebagai Variabel Pemoderasi. KURS, 1 (1).

Sumarsono, Sugeng. 2009. Dampak Kebijakan Desentralisasi Fiskal Terhadap Efisiensi Sektor Publik Dan Pertumbuhan Ekonomi di Jawa Timur. JESP. Vol,1 No.2. malang 